\title{
Отношение студентов ТИ (ф) СВФУ к укреплению здоровья средствами физической культуры и спорта
}

\author{
Полкова К.А., студентка, \\ Технический институт (филиал) \\ Северо-Восточного федерального университета, г. Нерюнгри \\ E-mail: kpolkova@inbox.ru
}

\section{Научный руководитель: к.n.н., доцент Прокопенко Л.А.}

Активная физическая деятельность имеет положительное влияние на здоровье людей. Этому неоспоримому доводу посвящено бесчисленное количество исследований. Если излагать их суть кратко и по существу, то положительное влияние физической культуры и спорта на здоровье сводится к следующим конкретным факторам.

Укрепление опорно-двигательного аппарата, благодаря повышению устойчивости костей к нагрузкам, улучшению подвижности суставов, увеличению силы мышц, снижает риск развития остеохондроза, остеопороза, атеросклероза, артроза, грыжи межпозвоночных дисков.

Благодаря укреплению и развитию нервной системы, наблюдается возрастание скорости нервных процессов, что приводит к быстрому реагированию мозга на внешние раздражители и принятию верных решений. Этому способствует увеличение быстроты и ловкости движений, улучшение координации. Происходит беспрестанное формирование новых условных рефлексов, закрепляющихся и складывающихся в определенную последовательность. Организм начинает приспосабливаться к возрастающим нагрузкам, выполнять упражнения становится гораздо проще и эффективнее, а усилий прилагается меньше.

Улучшение функции сосудов и сердца сводится к тому, что кровеносные сосуды и сердечная мышца становятся выносливее. Во время тренировок сосуды и сердце начинают перекачивать больше насыщенной кислородом крови, объем которой за минуту повышается до 10-20 литров, вместо 5 литров.

Улучшается работа органов дыхательной системы в результате возрастающей потребности органов и тканей в кислороде во время нагрузок, что увеличивает глубину и интенсивность дыхания. На фоне отсутствия нагрузок объем кислорода, проходящий через органы дыхания за 60 секунд, составляет 8 литров, а во время плавания, бега, занятий в спортзале возрастает до 100 литров.

Повышение защитных функций организма (иммунитета) и качественное изменение состава крови - прямое доказательство положительного воздействия физкультуры. Люди, постоянно занимающиеся каким-либо видом спорта или посещающие тренажерный зал, гораздо реже болеют, быстрее выздоравливают. Число эритроцитов, содержащихся в кубическом миллиметре, у постоянно тренирующихся людей повышается с 5 до 6 миллионов. Возрастает уровень белых кровяных телец лейкоцитов, нейтрализующих вредоносные факторы.

Улучшение метаболизма - в натренированном организме гораздо лучше происходит процесс регулирования содержания в крови сахара и прочих веществ. 
Высокий уровень физической подготовленности, достигнутый в процессе тренировок, является индикатором крепкого здоровья и высокой работоспособности, создает предпосылки для успешной профессиональной деятельности, повышения адаптации организма к различным условиям.

Неоспоримый факт двигательной активности - изменение у людей отношения к жизни. Ведущие активный образ жизни люди в меньшей степени подвержены перепадам настроения, неврозам, депрессии, менее раздражительны и более жизнерадостны.

У студентов, занимающихся физической культурой и спортом, повышается способность адаптации организма к факторам окружающей среды. Они более устойчивы к неблагоприятным внешним воздействиям, психологическим стрессам, лучше переносят умственную и физическую усталость, к тому же, безусловно, укрепляется здоровье.

Известно, что здоровье зависит как от внешних условий, образа жизни, так и от индивидуального ответственного отношения человека к здоровьесбережению. Следует отметить, что, ученые, в основном, рассматривают аспекты анализа состояния здоровья студентов, оценку и диагностику здоровья студенческой молодежи, предлагают здоровьесберегающие системы, структуры, модели укрепления и сохранения здоровья студентов вуза. Однако формированию адекватного отношения к здоровью студенческой молодежи уделяется недостаточно внимания, а ведь одним из условий формирования здорового образа жизни является именно личное отношение студентов к своему здоровью.

В настоящее время студенты не всегда объективно оценивают свое здоровье. Их оценки часто носят субъективный характер, так как зависят от многих факторов: психологических особенностей студента, его самочувствия в момент исследования, состояния здоровья окружающих, частоты и тяжести заболеваний, перенесенных респондентом в последние годы, информированности о результатах медицинского обследования, состояния окружающей среды, степени удовлетворенности уровнем медицинского обслуживания и др. Понятие «отношение к здоровью» включает в себя: оценку состояния здоровья; отношение к здоровью как одной из основных жизненных ценностей; деятельность (действие) по сохранению и укреплению здоровья.

В современных научных работах одним из ключевых предметов исследования является здоровье студентов. Физическая культура как средство сохранения и укрепления здоровья студентов представлена в трудах А.А. Мухамадиевой и А.Ф. Мифтахова [5]. Стараниями Е.М. Берестовой и С.С. Гордеевой рассмотрено ценностное отношение студенческой молодежи к здоровью [2]. Роль физической культуры в сохранении и укреплении здоровья человека представлена в работах Е.В. Еремка и др. [3]. В.Б. Мандриковым и И.А. Ушаковым изложены технологии оптимизации здоровья, физического воспитания и образования студентов медицинских вузов [4].

Цель исследования - определить отношение студентов к физической культуре, как к средству сохранения и укрепления здоровья.

Организация и методы исследования. В исследовании приняли участие студенты 1-3 курсов, обучающиеся в ТИ (ф) СВФУ на очном отделении. Общее количество опрошенных составило 97 человек, из них 41 юноша и 56 девушек. Анкетный опрос проведен в 2016 г.

Результаты исследования и их обсуждение. 
На вопрос о приоритете занятий физкультурой для себя студенты отметили следующее (табл. 1).

Таблица 1

Приоритеты студентов к занятиям физической культурой

\begin{tabular}{|l|c|}
\hline Варианты ответа & $\begin{array}{c}\text { Количество } \\
\text { ответов, \% }\end{array}$ \\
\hline Нравится заниматься, так как приятна мышечная нагрузка & 43 \\
\hline Считаю модным и престижным заниматься физкультурой & 24 \\
\hline $\begin{array}{l}\text { Охотно бы занимался, но не хватает стимула, чтобы «подстегнуть } \\
\text { себя» }\end{array}$ & 17 \\
\hline Без удовольствия хожу на занятия, так как нет желания и цели & 10 \\
\hline Саморазвитие & 6 \\
\hline
\end{tabular}

Ответы показывают, что большей части студентов нравится заниматься, так как приятна мышечная нагрузка и это полезно для здоровья. Но есть и студенты, которые не имеют ни желания, ни цели, поэтому без удовольствия ходят на занятия.

Важность занятий физической культуры и спорта для здоровья студентов можно проследить по табл. 2.

Таблица 2

Важность занятий физической культуры и спорта для здоровья студентов

\begin{tabular}{|l|c|}
\hline «Физическая культура и спорт для здоровья - это...» & Ответило «За», \% \\
\hline Быть здоровым и иметь хорошее самочувствие & 45 \\
\hline Здоровый образ жизни, способ быть в форме & 35 \\
\hline Способ преодоления болезней & 15 \\
\hline Повышение иммунитета & 5 \\
\hline
\end{tabular}

Из ответов видно, что важность занятий физической культурой в вузе для студентов определяется направленностью на здоровье, здоровый образ жизни, поддержание своей физической формы, что решает основную задачу занятий физической культурой и спортом по укреплению здоровья.

Оценка уровня физической подготовленности по 5 основным физическим качествам показала в основном средний уровень подготовленности студентов (табл.3).

Таблица 3

Оценка физической подготовленности студентов (в \%)

\begin{tabular}{|l|c|c|c|c|c|}
\hline \multirow{2}{*}{ Контингент } & \multicolumn{5}{|l|}{ Кол-во студентов, выполнивших контрольные нормативы физической } \\
& 1 балл & 2 балла & 3 балла & 4 балла & 5 баллов \\
\cline { 2 - 6 } & 3,89 & 11,03 & 55,16 & 21,12 & 8,77 \\
\hline $\begin{array}{l}\text { Весь } \\
\text { контингент }\end{array}$ & 5,35 & 19,64 & 51,78 & 17,85 & 5,35 \\
\hline Девушки & 2,43 & 2,43 & 58,54 & 24,39 & 12,19 \\
\hline Юноши & \multicolumn{5}{|c|}{} \\
\hline
\end{tabular}

Как мы видим, уровень подготовленности девушек оказался значительно ниже, чем у юношей. 
Далее мы поставили задачу: определить, как справляются студенты с предложенной нагрузкой на учебно-тренировочных занятиях. Определение велось по самочувствию. Результаты ответов представлены в табл. 4.

Таблица 4

Самочувствие студентов на занятиях физической культурой

\begin{tabular}{|l|c|}
\hline «Ваше самочувствие на занятиях по ФКиС» & $\begin{array}{c}\text { Количество } \\
\text { ответов, \% }\end{array}$ \\
\hline Хорошее (ощущение силы и бодрости, желание заниматься) & 59 \\
\hline Удовлетворительное (небольшая вялость) & 35 \\
\hline Неудовлетворительное (заметная слабость, утомление, головные боли) & 6 \\
\hline
\end{tabular}

Больше половины опрошенных справляются с нагрузкой, имеют хорошее самочувствие во время и после занятий. 35\% чувствуют небольшую вялость, отмечая состояние как удовлетворительное. 6\% студентов имеют неудовлетворительное самочувствие, которое характеризуется заметной слабостью, утомлением и головными болями, что может быть причиной ухудшения состояния здоровья или недостаточной подготовленности к предложенным нагрузкам.

При проведении анкетирования мы также постарались выяснить, какие темы методико-практического раздела интересуют больше всего студентов. Большинству студентов наиболее интересна тема «Средства и методы мышечной релаксации», раскрывающая вопросы профилактики и борьбы со стрессами. И это понятно. Студенческий период сопровождается стрессовыми ситуациями 2 раза в год во время экзаменационных сессий.

Заключение. Анализ отношения студентов к физической культуре показал, что большая часть студентов осознает всю пользу занятий физкультурой и ее непосредственное влияние на их здоровье, которое выражается хорошим самочувствием, получением приятной мышечной нагрузки. Но также исследование показало, что, к сожалению, студенты в настоящее время не уделяют должного внимания физической активности в свободное время. Ведь только благодаря регулярным занятиям как в учебное, так и в свободное время, возможно добиться высоких результатов в сохранении и укреплении своего здоровья.

Список литературы:

1. Влияние физкультуры и спорта на организм // Ваш СПОРТ [Электронный pecypc]. - Режим доступа: http://vashsport.com/sport-i-zdorove/

2. Гордеева С.С., Берестова Е.М. Ценностное отношение студенческой молодежи к здоровью// Молодежный научный форум: Общественные и экономические науки: электр. сб. ст. по материалам IX студ. междунар. заочной науч.-практ. конф. [Электронный ресурс]. - М.: «МЦНО». - 2014. - № 2(9). Режим доступа: https://nauchforum.ru/archive/MNF_social/2(9).pdf

3. Еремка Е.В., Балакирева Е.А., Терещенко И.В., Баланова С.Г., Шокотко Т.В. Роль физической культуры в сохранении и укреплении здоровья человека / Е.В. Еремка, Е.А. Балакирева, И.В. Терещенко, С.Г. Баланова, Т.В. Шокотко [Электронный pecypc]. - Режим доступа: http://bmsi.ru/doc/66c87b7b-bd76-4683-9fa4-5265d62b97e4

4. Мандриков В.Б., Ушаков И.А. Технологии оптимизации здоровья, физического воспитания и образования студентов медицинских вузов / В.Б. 
Мандриков, И.А. Ушаков // Теория и практика физической культуры. - 2016. - № 8. - С 37.

5. Мухамадиева А.А. Физическая культура и спорт как средства сохранения и укрепления здоровья студентов // Научное сообщество студентов XXI столетия. Гуманитарные науки: сб. ст. по мат. XXV междунар. студ. науч.-практ. конф. № 10(25). [Электронный ресурс]. - Режим доступа: http://sibac.info/archive/guman/10(25).pdf (дата обращения: 21.03.2017)

\title{
Миграция хлоридов в снежном покрове Центральной Якутии
}

\author{
Потапова С.А., аспирант, \\ Институт мерзлотоведения СО РАН им. П.И. Мельникова \\ E-mail: stellapotapova93@mail.ru
}

Научный руководитель: о.2.-м.н., профессор Макаров В.Н.

Центрально-Якутский комплексный геокриологический стационар «Туймаада» (КГСТ) располагается в Центральной Якутии на 2 надпойменной террасе p. Лены и представляет собой почти горизонтальную поверхность с альтитудой около 110 м.

Автором на территории КГСТ проведен мониторинг физических характеристик химического состава снежного покрова в период январь-апрель 2016 г. Пробы снега отбирались на ровной луговой площадке размерами 6х6 м в центральной части КГСТ. В 10 метрах от площадки мониторинга находится установка по сбору атмосферных осадков (рис. 1).

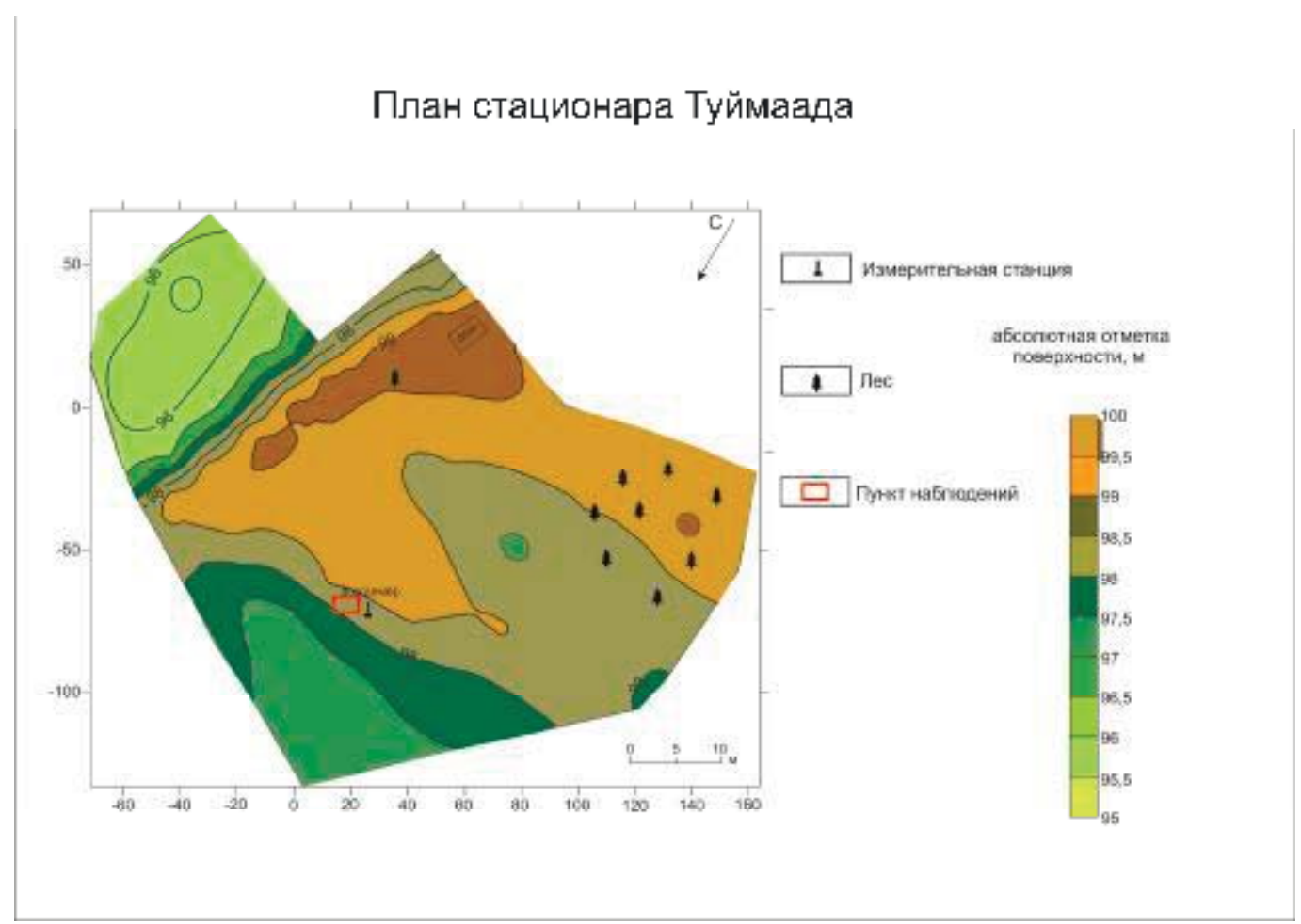

Рис. 1. Положение площадки мониторинга снежного покрова на КГСТ 